\title{
Teropong Warung Lesehan di Tegal
}

\author{
Oleh: Fathurozi \\ Staf Balai Penelitian dan Pengembangan Agama Semarang
}

\begin{abstract}
JARUM jam menunjuk pukul 17.00 WIB, berangkat dari Semarang mengenderai sepeda motor menuju arah barat. Malam itu, sekitar jam 20.00 WIB, tiba di kota Tegal. Tuk mengobati rasa kangen atas tanah kelahiran, Saya sempatkan diri keliling kota dari Mal Pasifik ambil jalur keselatan hingga ke Slawi. Sepanjang trotoar jalan, warung lasehan di jejali anak-anak muda.
\end{abstract}

Rasa penasaran semakin menjadi, sambil melepas lelah, saya menyambangi salah satu warung lesehan di daerah Adiwerna. Di pojok tenda terlihat, karyawan centil dengan sentuhan-sentuhan nakal mengoda pembeli. Tiap malam Minggu, warung tersebut di penuhi anak baru gede $(A B G)$, mereka nongkrong hingga larut malam. Iringan musik menjadikan suasana hangat.

Moci sudah jadi tradisi turun temurun, hampir tiap hari, ritual minum teh dilakukan masyarakat Tegal, baik mau berangkat kerja hingga pulang kerja. Seiring berjalannya waktu, warung lesehan berubah jadi warung remang-remang atau di duga sebagai tempat praktek prostitusi.

Warung ini, asal mula menyediakan bagi masyarakat yang mencari jajanan karena kebiasaan anak muda di wilayah ini, bergadang dalam bahasa Tegal (lek-lekan) hingga larut malam. Warung-warung seperti ini, tak jauh beda dengan warung poci di simpang lima, Semarang, yang sempat meresahkan kota Atlas. Namun pemerintah berhasil mengatasi problem tersebut.

Kota dengan slogan Sing Mbetahi Lan Ngangeni, masyarakat yang pernah berkunjung ke daerah ini, memiliki rasa nyaman. Ketika malam sudut kota begitu indah, tersedia fasilitas yang mempuaskan baik itu pariwisata alam, kuliner, pusat-pusat perbelajaan, tapi akhir-akhir ini, pengujung terusik dengan warung poci yang disalah gunakan.

\section{Penyakit Masyarakat}

Masyarakat Kabupaten Tegal dikejutkan dengan temuan penyakit HIV/AIDS, bagi penderitanya bisa saja merenggut ajal. Bahkan dikalangan kedokteran belum menemukan obat penawar, bila pun ada hanya sifatnya pencegahan. Berdasarkan data Dinas Kesehatan (Dinkes) Kabupaten Tegal, tahun 2006 hingga bulan September 2010 terdapat 118 warga mengidap HIV/AIDS, dari jumlah itu, 90 orang positif HIV dan sisanya penderita penyakit AIDS, (Suara Merdeka, 22 Oktober 2010).

Menurut data Dinas Kesehatan Kabupaten Tegal, tercatat hingga bulan September 2011 penderita HIV/AIDS mencapai 173 orang dan 23 meninggal dunia. Begitu pesatnya peredaran penyakit ini, mungkin saja disebabkan banyak tempat lokalisasi yang berkedok warung lesehan, padahal di Tegal ada empat lokalisasi yakni lokalisasi Peleman, Desa, Sidoarjo, Kecamatan Suradadi, Wandan dan Gang Sempit Maribaya, Dukuh Pengasinan, 
Kecamatan Kramat, Karanggondang. PSK (Pekerja Seks Komersial) mulai berani turun ke jalan penghubung kota untuk menjajakan cinta.

Biasanya lokalisasi liar ini, di seputar Jalan Banjaran, Adiwerna dan Jalan A. Yani, Slawi. Masyarakat luar kota akan lebih mengenal dua Lokalisasi yakni Peleman dan Wandan. Namun keberadaan PSK sangat mengkhawatirkan masyarakat, sebagian besar PSK mulai terjangkit Human Immunodeficiency Virus (HIV) dan Acquired Immunodeficiency Syndrome (AIDS). Penyakit ini, dari tahun ke tahun mengalami peningkatan signifikan.

\section{Pudarnya Simbol Poci}

Konon keluarga yang belum di karunia anak, maka keluarga tersebut akan melakukan ritual mantu poci. Mantu poci dirayakan seperti perayaan pernikahan sepasang manusia mulai menyebar undangan hingga proresi akad nikah.

Kehadiran warung lesehan cukup menodai tradisi ini, bahkan tampak tempat itu seperti lokalisasi, masyarakat yang ingin membeli makanan, mengurungkan niatnya. Mungkin saja, khawatir di sangka berbuat macam-macam dan takut tertular.

Suatu ketika, penulis bertanya ke beberapa warga sekitar tentang warung poci atau lesehan, menurut warga, warung-warung ini, asal mulanya tak meresahkan, Namun seiring berjalannya waktu, pemilik warung menghadirkan cewek-cewek yang berpenampilan seksi, menarik penguna jalan mampir ke tendanya.

Padahal pemerintah pernah melakukan sosialisasi dengan mengumpulkan 22 pemilik warung, yang memiliki 27 lokasi dan di buat lah kesepakatan yang berisi yaitu pertama, tidak berjualan di trotoar jalan, kedua menjalankan usaha warung secara murni atau tanpa unsur prostitusi maupun miras, ketriga memasang penerangan yang cukup, kelima menjaga ketertiban umum dan siap menerima sanksi dari Pemkab Tegal. Namun, realita yang ada pengelola warung tak mengindahkan himbuan tersebut.

Jangan sampai tradisi minuman teh, yang terkenal di nusantara tercemar karena moci menjadi simbol kerukunan masayarakat. 